\title{
Body composition of Sri Lankan children: Effects of ethnicity
}

\author{
V Pujitha Wickramasinghe ${ }^{1}$ \\ Sri Lanka Journal of Child Health, 2011; 40(3): 89-104 \\ (Key words: Body composition; Sri Lankan children; ethnicity effects) \\ DOI: http://dx.doi.org/10.4038/sljch.v40i3. 3506.
}

\section{Foreword}

President, Members of the Council of the Sri Lanka College of Paediatricians, Members of the Family of Prof C C de Silva, Distinguished Invitees, Ladies and Gentlemen. I consider this as an honour and privilege to be able to deliver this year's Prof C C de Silva oration and I thank the President and the Council for giving me this opportunity. I dedicate this oration to Professor Percival Cholomondley Chalmers de Silva who served this country as the first Professor of Paediatrics for 17 long years from 1949.

Nutrition and community paediatrics were two areas close to his heart and he was instrumental in establishing institutes like the Nutrition Society of Sri Lanka and the Nutrition Convalescence Home in Thalagolla, which concept has now been absorbed by WHO also as part of management of acute severe malnutrition. His contributions to the scientific literature were immense and he has many publications in international journals especially in the field of nutrition. He was a keen writer and his contribution to non scientific literature left a legacy of amusement in the reader.

Although I was not privileged to meet or be taught by Prof C C de Silva, I was guided by those who had the privilege of studying under him. As Prof C C de Silva had a keen interest in community paediatrics and nutrition, I hope the work I present here will be a tribute to him as it covers community paediatrics with relevance to nutrition.

\section{Introduction}

Living beings, like any other physical matter, are composed of tissues, compounds, molecules and atoms. The curious man began to analyse himself and led body composition to evolve as a new branch of

${ }^{1}$ Senior Lecturer, Department of Paediatrics, Faculty of Medicine, University of Colombo, Sri Lanka science focusing on the qualitative assessment of body with changes that occur in health and disease ${ }^{1}$.

The history of body composition assessment can be traced back to the 5th century BC when Hippocrates proposed that the whole body is composed of blood, phlegm, black bile and yellow bile. Chinese scholars also had proposed five elements in the human body: metal, wood, water, fire and earth. Avicenna in the 10th Century AD, from the Arabic world, tried to provide knowledge of organ sizes. Interest in human body composition grew steadily over the last 150 years and advances in technology paved the way for in vivo assessment. Use of body composition was not limited to the science laboratory, but spanned the clinical wards as well ${ }^{1}$.

\section{Clinical use of body composition}

Biochemical and immunological tests complement clinical findings in diagnosing and treating diseases. Associated changes in body composition are sometimes more sensitive than biochemical markers. This is useful in management of certain diseases such as malnutrition (over and undernutrition), renal disorders, liver disorders, malignancies, burns, trauma, gastrointestinal disorders and cardiovascular disease $^{2}$.

Simple methods that are used to assess body composition in a low budget setting are height, weight, body mass index (BMI), skinfold thickness (SFT) and circumference measurements [waist, hip, mid upper arm circumference (MUAC)]. Bioelectrical impedance assay (BIA) and dual energy x-ray absorptiometry (DEXA), independently offer more detailed assessment of body composition. Computed tomography (CT) and magnetic resonance imaging (MRI) are useful in the assessment of regional fat distribution ${ }^{2}$. Region to be assessed, availability of equipment and trained staff, state of the patient (ambulant or bed bound) and the setting (research, clinical, epidemiological) are factors that 
need to be considered in selecting the assessment method $^{2}$. BIA is a simple technique that offers assessment of body fat and muscle mass using simple equipment. This new technique has revolutionized body composition assessment and made it a more clinically useful tool.

A change in weight or BMI does not provide information about the specific changes that occur in body composition, but only indicates an overall change in body mass. However, effects of disease are directly related to certain components of body composition. Therefore, effects of treatment should be assessed based on the changes that take place in the particular area or component of body rather than changes in the whole body. Hence, assessment of body composition is superior to the use of anthropometric methods to measure clinical outcomes.

\section{Factors affecting body composition}

Age, pubertal stage, levels of physical activity (athletes), physiological state (childhood, pregnancy etc), ethnic origin and the disease state influence body composition. These factors have made each of these categories to have a unique body composition. Therefore, use of body composition assessment methods and cutoff values across all ethnic groups/populations are of doubtful value.

South Asian populations are well known to have quite a different body composition, i.e. relatively high fat mass (FM) in the body for any given BMI value $^{3}$. This is associated with many non communicable diseases and undoubtedly could be a reason for the high prevalence of non communicable diseases in this group. A better understanding about body composition would be helpful in understanding and controlling many non communicable diseases. Similarly, differences in body composition could affect results of different assessment methods. Therefore, it is important to validate existing methods prior to their use or develop appropriate methods to suit these ethnic groups.

As body composition of Sri Lankan children has not been studied before, I embarked on this research project to study the body composition of 5-15 year old Sri Lankan children. It is a crucial period in life where changes in body composition will have long lasting effects on health. This study was conducted in two phases. The first phase was to assess body composition of Sri Lankan children using isotope dilution (assessed by $\mathrm{D}_{2} \mathrm{O}$ ), to evaluate the appropriateness of different BMI based cutoff values in screening for overweight and obesity and develop new BMI cutoff values for Sri Lankan children, to evaluate the appropriateness of bioelectrical impedance assay and other anthropometry based equations in the assessment of body composition and to develop body composition assessment techniques suitable for Sri Lankan children. The second phase was to assess the body composition of Australian children of Sri Lankan origin and compare with Sri Lankan children to evaluate the impact of socioeconomic environment and ethnic origin on body composition and to assess the appropriateness of the newly developed body composition assessment techniques.

\section{Phase I of the study}

\section{Materials and methods}

\section{Determination of sample size}

Sample size was determined to achieve a coefficient of determination of $80 \%$ and a single variable change to make a $5 \%$ variable increase. A sample of 100 children achieves $100 \%$ power assuming a significance level (alpha) of 0.05. One hundred from each sex [10 from each age category (5-15 years) of each sex] would be sufficient to develop the prediction formulae. PASS 2000 (Hintze, Kayswille, Utah, USA) statistical programme was used for the calculation of sample size. Fifty more children from each group were recruited to allow for dropouts. Three hundred children (150 boys and 150 girls), living in Sri Lanka were recruited from schools in Colombo based on two-stage probability proportionate cluster sampling technique. One class from each grade, 1 to 10 , were selected randomly and all students in each class were invited to participate. Students to a class are selected randomly; therefore it was not considered necessary to invite randomly. Children who were willing with parents' consent were recruited and asked to come to the Professorial Paediatric Unit at Lady Ridgeway Hospital, Colombo, Sri Lanka, where all tests were performed.

This is the very same laboratory that Prof C C de Silva started. It survived a long arduous course where from time to time many wanted it to be removed from the professorial unit. We were able to reorganize it to be used as a clinical research laboratory and it was possible to carry out research such as this one without much interference from ward work, involving healthy volunteers. Today, in this laboratory I have been working on obesity related research which is on the other end of the spectrum which Prof C C de Silva worked half a century ago. 


\section{Total body water (TBW) measurement}

TBW was measured by the isotope dilution method using naturally occurring, stable, non-radioactive isotope of hydrogen, deuterium, in the form of water $\left(\mathrm{D}_{2} \mathrm{O}\right)$. The procedure began with the subject emptying his/her bladder and collecting a sample (10 $\mathrm{ml}$ ) of urine into a screw cap bottle. This was used to determine basal $\mathrm{D}_{2} \mathrm{O}$ levels. A $10 \% \quad \mathrm{D}_{2} \mathrm{O}$ dose of $0.5 \mathrm{~g} / \mathrm{kg}$ body weight was given, the dose being measured to $0.01 \mathrm{~g}^{4}$. A second sample of urine $(10 \mathrm{ml})$ was collected into a screw cap bottle 4-6 hours after administrating the $\mathrm{D}_{2} \mathrm{O}$ dose to ensure equilibration with body water ${ }^{5} . \mathrm{D}_{2} \mathrm{O}$ in the collected urine samples was measured using isotope ratio mass spectrometry (Hydra, Europe Scientific Crewe, UK) at the Children's Nutrition Research Centre, University of Queensland, Australia. One ml of urine from each collected sample was appropriately packed and air freighted to Australia in air tight containers to reach the destination within 48 hours. Technique of assessment and calculating TBW described by Halliday and Miller ${ }^{6}$ was used. From TBW, fat free mass (FFM) and hence fat mass (FM) was calculated using age and gender specific water content of $\mathrm{FFM}^{7}$. Therefore, FFM = TBW/ Percent water in FFM.

\section{Anthropometry}

All measurements were done with minimum lightweight clothing. Height was measured with a stadiometer to the last completed $0.1 \mathrm{~cm}$ (Surgical and Medical products, Brisbane, Australia) with occiput, back of chest, buttock and heel touching the vertical plane and head kept in horizontal Frankfurt plane. Weight was measured to the closest $100 \mathrm{~g}$ using an electronic weighing scale (Soehnle ${ }^{\circledR}$ SoehnleWaagen $\mathrm{GmbH} \& \mathrm{Co}$, Germany). Waist circumference (WC) was measured with the subject standing erect with abdomen relaxed, arms at the sides of the body and feet together. The measurement was taken in the horizontal plane, at the level of midpoint between the costal margin and the iliac crest in the mid axillary line. Hip circumference was measured with the subject standing erect with the arms by the sides of the body and feet together. The circumference was measured at the maximum extension of the buttocks seen from the lateral side ${ }^{8}$.

\section{Skinfold thickness measurements}

SFT of the following sites were measured using a Harpenden caliper (John Bull, British Indicators Ltd, $\mathrm{UK}$ ) to the closest $1 \mathrm{~mm}$ on the left side of body. The caliper pressure was $10 \mathrm{~g} / \mathrm{cm}^{2}$ and measurements were taken 2-3 seconds after applying caliper jaws'. Triceps SFT was measured at the mid point between the lateral projection of the acromion and inferior surface of the olecranon process with the arm flexed $90^{\circ}$ at the elbow. The measurement was taken with the arm hanging freely at the side of trunk and the palm facing the lateral aspect of thigh. A vertical skin fold over the triceps muscle was measured. Biceps $S F T$ was measured as the thickness of a vertical fold raised on the anterior aspect of the arm over the belly of the biceps muscle at the same level the triceps SFT was measured. Arm was hanging by the side with the palm directed anteriorly. Forearm SFT was measured with the subject standing with arms relaxed and palms facing the lateral aspect of thigh. A vertical skin-fold in the midline of the posterior aspect of the forearm at the level of the maximum circumference was measured. Mid anterior thigh SFT was measured by grasping a vertical fold of skin midway between the mid point of the inguinal crease and the proximal border of the patella. Measurement was taken with the subject standing erect. Medial calf SFT was measured with the subject seated and the measured foot kept on the ground and knee flexed to $90^{\circ}$. A vertical skinfold on the medial side of the calf at mid point between the lateral malleolus and the tibiofibular joint was measured. Subscapular SFT was measured as an infero-laterally inclined oblique (approximately $45^{\circ}$ to the horizontal plane) skinfold, immediately below the inferior angle of the scapula. Suprailiac SFT was measured in the mid axillary line. An infero-medially aligned oblique $\left(45^{0}\right.$ to the horizontal plane) skinfold immediately superior to the iliac crest was grasped and measured ${ }^{10}$.

\section{Bioelectrical impedance analysis measurement}

BIA was measured with single frequency $(50 \mathrm{kHz})$ four surface-electrode technique, with an electric current of $800 \mu \mathrm{A}$, using Bodystat instrument ${ }^{\circledR}$ (Bodystat Ltd, Isle of Man, British Isles). The subject lay supine on a bed with a non-conductive surface. Hands were kept in the prone position and slightly abducted so that they were not touching the trunk. Legs were abducted to have a minimum distance of $20 \mathrm{~cm}$ between the two medial malleoli to avoid thighs touching each other ${ }^{11}$. For the whole body impedance measurement, surface electrodes for the source current (discharging electrodes) were placed at the third metacarpo-phalangeal joint in the left hand and third metatarso-phalangeal joint of the left foot. The sensing electrodes were kept at midway between the styloid processors and malleoli of the left wrist and left ankle respectively. A minimum distance of $5 \mathrm{~cm}$ was maintained between the source and sensing electrodes to avoid any interference. If the natural length was less than $5 \mathrm{~cm}$, the sensing electrode was moved till the desired distance was achieved $^{11}$. Conduction gel coated disposable surface electrodes $\left(5 \mathrm{~cm}^{2}\right.$, Kendall Q-Trace 5400®, Ludlow Company Ltd, USA) were used and connected to the 
BIA machine via crocodile clips. Impedance index $\left(\mathrm{cm}^{2} \Omega^{-1}\right)$, is height square $(\mathrm{cm})$ divided by impedance $(\Omega)$.

\section{Diagnosis of obesity}

Percentage body fat associated with obesity related cardiovascular risk factors were considered to be over $25 \%$ for boys and $30 \%$ for girls ${ }^{12}$. Criterion for diagnosis of obesity was based on the above \%FM. Obesity was diagnosed using three BMI based methods. These were: the International Obesity Task Force (IOTF) BMI cutoff values ${ }^{13}$, CDC/NCHS BMI centile charts $\left(>95^{\text {th }} \text { centile }\right)^{14}$ and British Growth standard BMI-Z $\left(>^{+} 2\right)^{15}$. Additionally \%FM centile charts $\left(>98^{\text {th }} \text { centile }\right)^{16}$ and waist circumference centile charts $\left(>90^{\text {th }} \text { centile }\right)^{17}$ were used.

\section{Assessment of sensitivity of indices}

Validity and accuracy of BMI indicators in the diagnosis of obesity were evaluated by calculating sensitivity, specificity, positive predictive value and efficiency, relative to true obesity diagnosed by absolute $\%$ FM, using a $2 \times 2$ table ${ }^{18,19}$.

\section{Assessment of body composition using bioelectrical impedance analysis}

Eleven BIA equations published in the literature were used in the assessment of body composition of Sri Lankan children and they are listed elsewhere ${ }^{20}$.

\section{Assessment of body composition using SFT}

Five SFT equations used in the published literature were used in the assessment of body composition of Sri Lankan children and are listed elsewhere ${ }^{21}$.

\section{Validation of published prediction equations}

Body composition parameters estimated by each of the prediction equations were compared with the results obtained from the criterion method to assess the reliability of each of the prediction equations. Bias was calculated by subtracting the FM or $\% \mathrm{FM}$ assessed by criterion method, from the FM or $\% \mathrm{FM}$ estimated by prediction equations (predicted actual). Estimated FM and \%FM and bias in the estimation of FM and \% FM were compared between each gender using unpaired t-test. $\mathrm{P}<0.05$ was considered as significant based on two tailed t-test. Pearson's product moment correlation coefficient was calculated between the \%FM (or FM) assessed by the criterion method and each BIA prediction equation and between bias and the mean \%FM (or FM) assessed by the two methods (prediction equation and the criterion method). Body composition parameters assessed by the criterion method as well as the prediction equations for each gender group were compared using one way analysis of variance (ANOVA) of Bonferroni multiple comparison procedure. The $95 \%$ confidence interval (CI) for mean bias and limits of agreement (LOA) for bias were calculated from each prediction equation for each gender group as described by Bland and Altman $^{22}$.

\section{Development of new prediction equations}

Prediction equations were constructed by stepwise multiple regression analysis. Prediction equations were constructed separately taking TBW and FFM as the dependent variable and age, weight, height, BMI, gender, impedance index and different combinations of SFT in each analysis as the possible independent variables. Best prediction variables were selected by measure of goodness-of-fit statistics and best prediction equations were determined based on high $\mathrm{R}^{2}$ and minimum $\mathrm{RMSE}^{23}$. Initially a set of preliminary equations were formulated to estimate different body composition parameters (TBW, FFM, $\mathrm{FM}$ and $\% \mathrm{FM}$ ). Their robustness was tested on the validation group and results were compared using ANOVA. Bland and Altman ${ }^{23}$ method was used to assess the agreement between prediction equation and criterion method. Once the best predictor independent variables were identified, final prediction equations were developed on the whole study population and were statistically validated using PRESS (prediction of sum of squares) statistical method ${ }^{24,25}$.

\section{Data analysis}

Data was analysed using NCSS 2000 (Hintze JL, Kayswille, Utah, USA) statistical computer package for Windows.

Ethical review committees of Faculty of Medicine, University of Colombo, Lady Ridgeway Hospital, Colombo, Sri Lanka, University of Queensland and Royal Children's Hospital, Brisbane, Australia approved the relevant components of the project.

\section{Results}

\section{Study population}

Three hundred and nineteen children were recruited. Thirty seven $(11.5 \%)$ children were excluded from the final analysis due to different technical reasons (figure 1). 


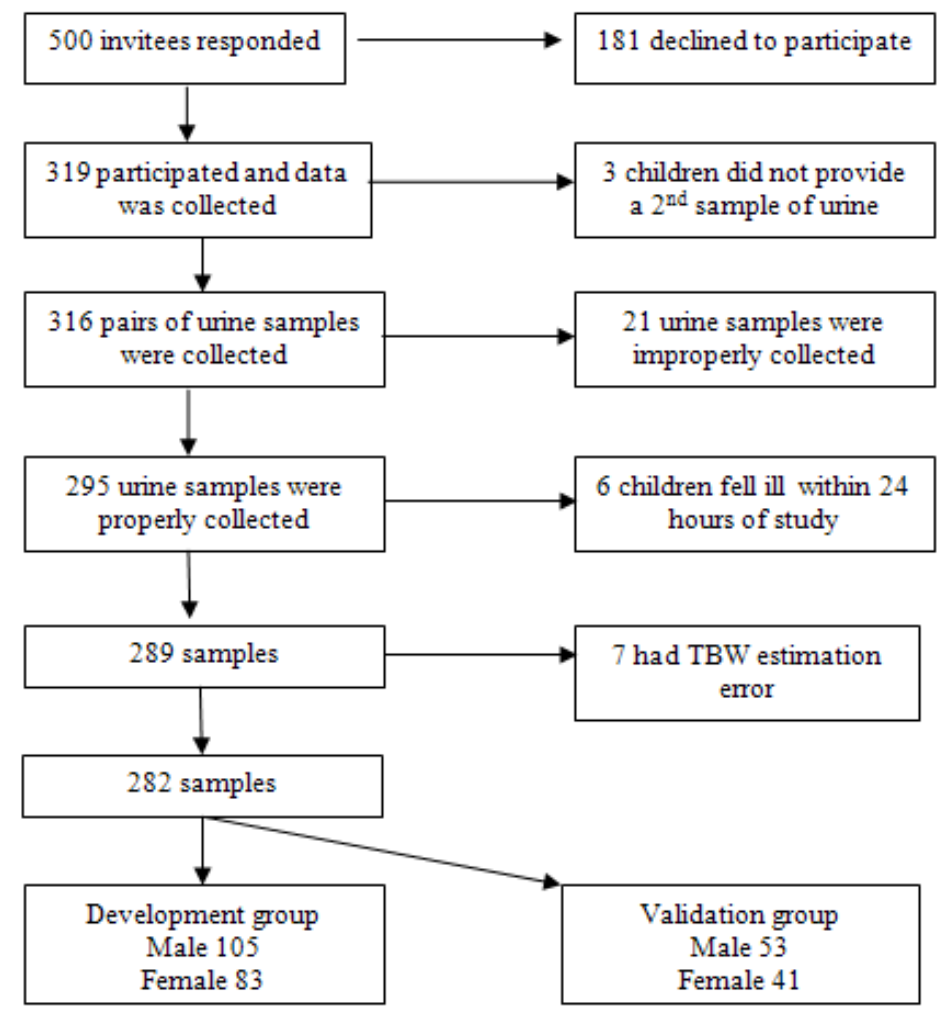

Figure 1: Recruitment procedure of the study population

Two hundred and eighty two data sets were included in the final analysis and two thirds of the group (188) was assigned to the development group and the remaining third (94) to the validation group (Figure $1)$. The characteristics of the study population are given in table 1 .

Table 1: Characteristics of development and validation groups of Sri Lankan children by gender

\begin{tabular}{|l|c|c|c|c|}
\hline \multirow{2}{*}{ Characteristic } & \multicolumn{2}{|c|}{ Male } & \multicolumn{2}{c|}{ Female } \\
\cline { 2 - 5 } & $\begin{array}{c}\text { Development } \\
\text { group }\end{array}$ & $\begin{array}{c}\text { Validation } \\
\text { group }\end{array}$ & $\begin{array}{c}\text { Development } \\
\text { group }\end{array}$ & $\begin{array}{c}\text { Validation } \\
\text { group }\end{array}$ \\
\hline Number & 105 & 53 & 83 & 41 \\
\hline Age $($ years) & $9.5 \pm 2.7$ & $9.6 \pm 2.7$ & $10.1 \pm 2.8$ & $10.1 \pm 2.8$ \\
\hline Weight $(\mathrm{kg})$ & $31.1 \pm 11.7$ & $31.3 \pm 14.0$ & $34.7 \pm 12.6$ & $35.5 \pm 13.0$ \\
\hline Height $(\mathrm{cm})$ & $134.5 \pm 14.9$ & $134.6 \pm 16.8$ & $138.4 \pm 15.5$ & $138.7 \pm 15.0$ \\
\hline BMI $\left(\mathrm{kgm}^{-2}\right)$ & $16.7 \pm 3.6$ & $16.5 \pm 4.1$ & $17.5 \pm 3.8$ & $17.9 \pm 3.8$ \\
\hline BMI Z score & $-0.39 \pm 1.8$ & $-0.72 \pm 1.9$ & $-0.19 \pm 1.6$ & $-0.03 \pm 1.6$ \\
\hline TBW $(\mathrm{L})$ & $17.0 \pm 5.3$ & $16.7 \pm 5.7$ & $16.4 \pm 5.8$ & $17.1 \pm 5.9$ \\
\hline FFM (kg) & $22.4 \pm 7.2$ & $22.0 \pm 7.7$ & $21.4 \pm 7.8$ & $22.4 \pm 7.9$ \\
\hline FM (kg) & $8.7 \pm 5.9$ & $9.3 \pm 7.8$ & $13.2 \pm 6.8$ & $13.2 \pm 6.9$ \\
\hline Percentage FM $(\%)$ & $26.0 \pm 9.8$ & $26.2 \pm 12.0$ & $37.5 \pm 10.4$ & $36.0 \pm 10.2$ \\
\hline Impedance $(\Omega)$ & $761.2 \pm 98.2$ & $763.2 \pm 102.8$ & $796.8 \pm 114.0$ & $783.5 \pm 92.5$ \\
\hline Impedance index $\left(\mathrm{cm}^{2} \Omega^{-1}\right)$ & $24.7 \pm 7.8$ & $25.1 \pm 8.9$ & $25.2 \pm 7.7$ & $25.6 \pm 7.6$ \\
\hline Triceps SFT $(\mathrm{mm})$ & $12.4 \pm 6.2$ & $12.2 \pm 7.6$ & $15.9 \pm 6.5$ & $15.3 \pm 6.0$ \\
\hline Sub scapular SFT $(\mathrm{mm})$ & $11.4 \pm 8.7$ & $11.6 \pm 9.9$ & $15.3 \pm 9.4$ & $15.7 \pm 9.4$ \\
\hline Supra iliac SFT $(\mathrm{mm})$ & $15.8 \pm 10.8$ & $15.6 \pm 12.6$ & $19.4 \pm 9.5$ & $19.7 \pm 10.8$ \\
\hline Biceps SFT $(\mathrm{mm})$ & $7.8 \pm 8.7$ & $7.8 \pm 5.6$ & $10.1 \pm 5.0$ & $9.8 \pm 4.8$ \\
\hline
\end{tabular}

$* \mathrm{p}<0.05$ between development and validation groups within each gender 
Validity of body mass index as a measure of obesity in Sri Lankan children

Ability of different BMI cut off values in diagnosing obesity in Sri Lankan children was evaluated (table 2).

Table 2

Cases of obesity and overweight diagnosed by different methods in Sri Lankan children by gender

\begin{tabular}{|l|c|c|}
\hline $\begin{array}{c}\text { Obesity determined } \\
\text { by }\end{array}$ & $\begin{array}{c}\text { Male } \\
\mathbf{( 1 5 8 )}\end{array}$ & $\begin{array}{c}\text { Female } \\
\mathbf{( 1 2 4 )}\end{array}$ \\
\hline & $\mathrm{n}(\%)$ & $\mathrm{n}(\%)$ \\
\hline$\% \mathrm{FM}\left(\mathrm{D}_{2} \mathrm{O}\right)$ & $72(45.5)$ & $99(80.0)$ \\
\hline IOTF cutoff & $9(5.7)$ & $8(6.4)$ \\
\hline NCHS/CDC cutoff & $14(8.8)$ & $16(13.0)$ \\
\hline BMI-Z $>2$ SD cutoff & $17(10.7)$ & $16(13.0)$ \\
\hline$\%$ FM centile & $61(38.6)$ & $81(65.0)$ \\
\hline $\begin{array}{l}\text { Waist Circumference } \\
\text { centile }\end{array}$ & $26(16.4)$ & $38(30.6)$ \\
\hline
\end{tabular}

Eighty percent of girls had a FM of more than $35 \%$ and $45.5 \%$ of boys had a FM more than $25 \%$. IOTF diagnosed only $6.4 \%$ girls and $5.7 \%$ boys as obese. NCHS/CDC centile cutoff as well as BMI-Z score diagnosed few more cases. Direct measurement of $\mathrm{FM}$ and use of $\% \mathrm{FM}$ centile charts were able to diagnose $65 \%$ girls and $39 \%$ boys to be obese. In both boys and girls, the BMI based cutoff had a very low sensitivity ranging from 8 to $23.6 \%$, but with high specificity (100\%). Percentage FM centile charts had a high sensitivity $(77.8 \%$ in boys and $81.8 \%$ in girls) and specificity (94.2\% in boys and $100 \%$ in girls) in diagnosing obesity ${ }^{26}$.

Similar results were seen in studies done among US children $^{27}$. In a group of 6-8 year old American children, $13 \%$ boys and $17 \%$ of girls were obese based on NHANES/WHO cutoff and only $8 \%$ of each group were obese based on IOTF cutoff. Similarly in the $12-14$ year age group, $11 \%$ of boys and $12 \%$ of girls were obese based on NHANES/WHO cutoff and $9 \%$ of boys and $10 \%$ of girls were obese based on IOTF cutoff. A study done in New Zealand showed that the IOTF had high specificity $(100 \%)$ in detecting obesity in Indian children but low sensitivity (54.5\%). Similar results were seen for Pacific Island children and authors concluded that IOTF cutoff values are not suited for the diagnosis of obesity in Indian and Pacific Island children and ethnic specific cutoff values would be more appropriate in assessing obesity in multiethnic populations $^{28}$.

Hattori chart plot helps to visually identify the relationship between FM and FFM for each age (figure 2$)^{29}$. It also shows $\% \mathrm{FM}$ (by interrupted diagonal lines) and BMI (by complete diagonal lines). It clearly shows that within a narrow belt of 2 units of BMI (between the two thick lines) fat percentage could be as low as low as $5 \%$ or even than $40 \%$ (depicted by arrows) (figure 2 ).

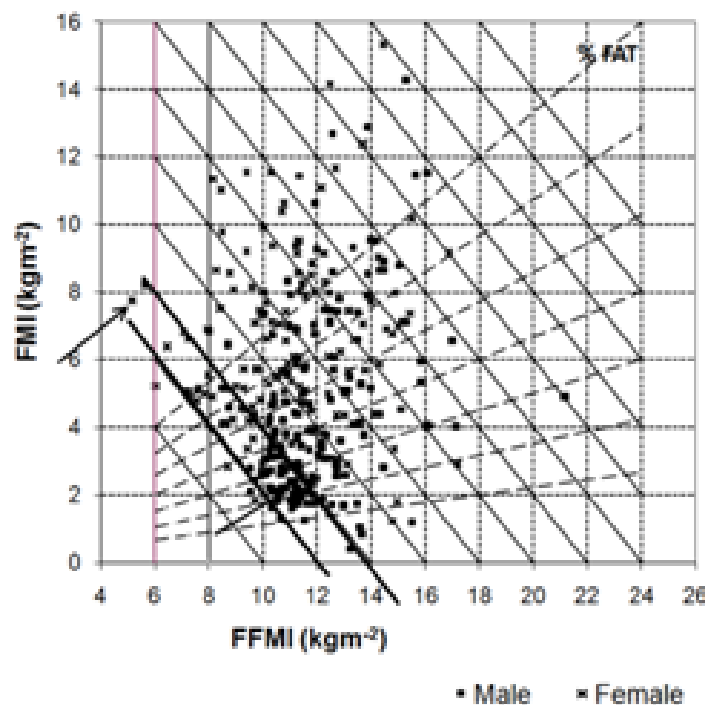

Figure 2: Hattori chart for Sri Lankan girls and boys

Furthermore with advancing age both mean FMI and FFMI (fat free mass index) increased (figure 3).

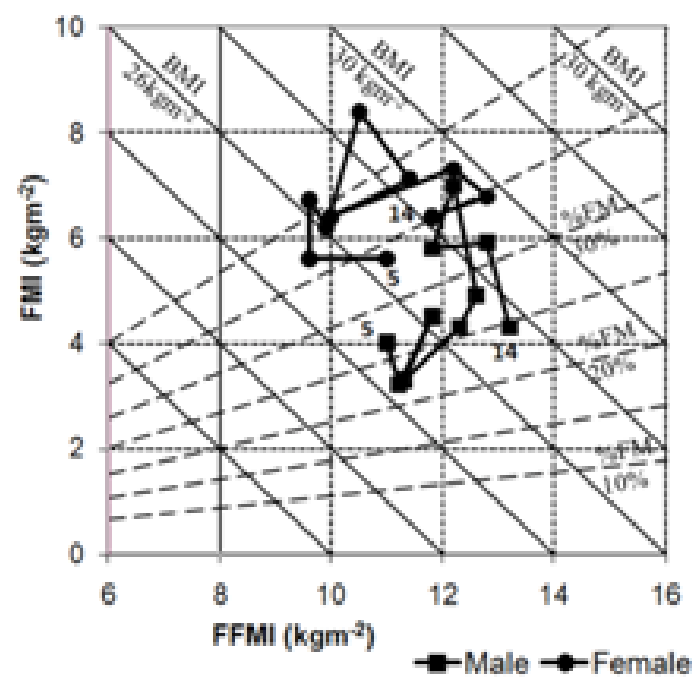

Figure 3: Hattori chart of mean FMI and FFMI for each age of each gender in Sri Lankan children

However, the increase is more in FMI. This shows that the increase in weight is mainly due to increase in fat content of body rather than an increase in FFM component. Sri Lankan children have high amount of 
fat in the body and most of the time weight gain occurs mainly due to gain in fat rather than an increase in both (FM and FFM) components proportionately (figure 3). It is clear that Sri Lankan children have more fat in the body at any given BMI values. Similar results were seen in a group of $\mathrm{New}$ Zealand children of Maori, Pacific Island, Indian and other Asian origins of the ages of 5-11 years. They were compared with children of European origin and at any given BMI value, Indian children had $4.3 \%$ more \%FM, while Pacific Island children averaged $1.7 \%$ less $\%$ FM than their European counterparts ${ }^{28}$.

One way of overcoming this problem of disproportionate reflection of \%fat mass in the body by BMI is to measure the FM directly. However, it may not be practical in clinical/epidemiological setting. Anthropometric techniques are easy to apply and cost effective, but they do not provide an accurate estimation of FM of the body. BMI is used in defining obesity and there are several published BMI cutoff values. These obesity cutoff values are based on population distribution of an anthropometric parameter rather than on a biological end point. Therefore the ability of BMI to diagnose obesity and overweight accurately has been questioned. There are many studies to show the low predictive value of BMI in detecting childhood obesity. Lazarus et al. ${ }^{30}$ showed that BMI had a true positive rate of $67 \%$ and false positive rate of $6 \%$ for predicting high $\mathrm{FM}$ in a group of 4-20 year old children and adolescents. Correlation coefficient of 0.85 was seen between BMI and FM assessed by DEXA in a group of 5-19 year old Italian children ${ }^{31}$. The correlation between FM and BMI in our study (Sri Lankan children) was $0.84(\mathrm{p}<0.001)$, but the correlation between $\% \mathrm{FM}$ and BMI was only $0.52(\mathrm{p}<0.001)$.

Unless ethnic specific relationships between BMI and FM are known, BMI could poorly predict the \%FM associated with health risks. There are even differences within the same ethnic group but living in different socio economic environments ${ }^{32}$. For any given BMI white Caucasians living in North America had a $4 \%$ higher $\% \mathrm{FM}$ than their counterparts living in Europe E $^{32}$.

The ability of BMI to diagnose obesity and overweight accurately, across different ethnic groups has been questioned ${ }^{33}$. This has led to a debate as to whether ethnic specific BMI cutoffs should be defined to diagnose overweight and obesity ${ }^{33}$ or indeed whether population specific cutoffs should be used across each country ${ }^{34}$. Although conclusions were not drawn at a WHO consultative meeting it was observed that BMI cutoff values in Asians for metabolic risk vary between $22-25 \mathrm{~kg} / \mathrm{m}^{2}$ BMI values $^{35}$.

\section{New BMI cutoff values}

New BMI cutoff values corresponding to a \%FM of $25 \%$ in boys and $35 \%$ in girls for each age have been derived and published for Sri Lankan children ${ }^{36}$. These values are significantly lower than the IOTF obesity values $^{36}$. Use of IOTF cutoff values leads to a large under-reporting of obesity. The new BMI values for eighteen year old Sri Lankan boys and girls are $19.2 \mathrm{kgm}^{-2}$ and $19.7 \mathrm{kgm}^{-2}$ respectively. Although these values appear quite low, similar results have been seen in another Sri Lankan study. Adult males and females studied for cardiovascular risk factors, the corresponding BMI associated with 2 or more CVD risk factors (high TG, HDL, BP or glucose) in males had been $20.7 \mathrm{kgm}^{-2}$ and females $22.0 \mathrm{kgm}^{-2}$ respectively ${ }^{37}$. A Canadian study recommended a BMI cutoff of $21.0 \mathrm{kgm}^{-2}$ for South Asian populations based on glucose metabolism ${ }^{38}$. The low cutoff values described in our study could be explained by the fact that we looked at the measured fat content of the body while the other studies have arrived at different cutoff values based on clinical outcomes which are in fact effects of accumulation of excess fat.

Waist circumference is another measure of adiposity. This represents central adiposity rather that overall fat content. Goran et $a l .{ }^{39}$ showed that trunk fat measured by DEXA correlated well with WC $(\mathrm{r}=0.83, \mathrm{p}<0.01$ in girls and $\mathrm{r}=0.84, \mathrm{p}<0.01$ in boys $)$. Furthermore they showed that WC correlated well with subcutaneous fat $(\mathrm{r}=0.93, \mathrm{p}<0.01)$ and intraabdominal fat $(r=0.84, p<0.01)$ measured by $\mathrm{CT}$. However waist hip ratio (WHR) was a poor predictor of trunk fat ${ }^{40}$.

In a group of Sri Lankan children, WC showed a statistically significant correlation with mean peritoneal fat $(\mathrm{r}=0.63 ; \mathrm{p}<0.01)$ and mesenteric fat $(\mathrm{r}=0.38 ; \mathrm{p}<0.01)$ measured ultrasonically ${ }^{41}$. WHR showed poor association with intra abdominal fat. WC detected $30.6 \%$ girls and $16.4 \%$ boys to be obese (table 2). A new set of WC cutoff values corresponding to a $\% \mathrm{FM}$ of $25 \%$ in boys and $35 \%$ in girls were derived. These values are comparable to the $90^{\text {th }}$ centile value of British $\mathrm{WC}$ values ${ }^{36}$. The corresponding WC values in an eighteen year old Sri Lankan boy and girl is $68.4 \mathrm{~cm}$ and $70.4 \mathrm{~cm}$ respectively. Although these values appear quite low, they are quite close to available other Sri Lankan data (males $76.5 \mathrm{~cm}$ and females $76.3 \mathrm{~cm})^{37}$. 
Diagnosis of obesity would be best done by direct assessment of FM. Power et $a l^{42}$ outlined qualities that a fat assessment method should possess but appreciated that at present there is no perfect tool for in vivo FM assessment. The option remains between the sophisticated direct body composition techniques (DEXA, BodPod®, CT, MRI and BIA) or anthropometric methods (weight, weight/height ratio, BMI, WC, SFT). Out of these techniques, only BIA could be used to assess FM accurately in clinical and epidemiological settings with portable, less expensive equipment in minimum time and discomfort to the subject. It assesses FM using mathematical equations and therefore need validation ${ }^{43,44}$. Direct measure of $\%$ FM would provide more accurate results and help to identify changes to treatment more precisely. British \%FM reference charts were developed using BIA technique ${ }^{16}$.

\section{Bioelectrical Impedance Assay}

The conductive properties of tissue are due to their dissolved electrolytes. Therefore conductive properties of body are mainly confined to FFM. Over years this method gained popularity due to its relatively low cost, operator simplicity and portability. This is probably the most frequently used body composition analysis method ${ }^{45}$ and the method of assessment is quite simple (vide supra).

Eleven prediction equations were validated on Sri Lankan children and they did not give satisfactory assessment of body composition of Sri Lankan children (figure 4) and the bias in assessment was quite high ${ }^{20}$.

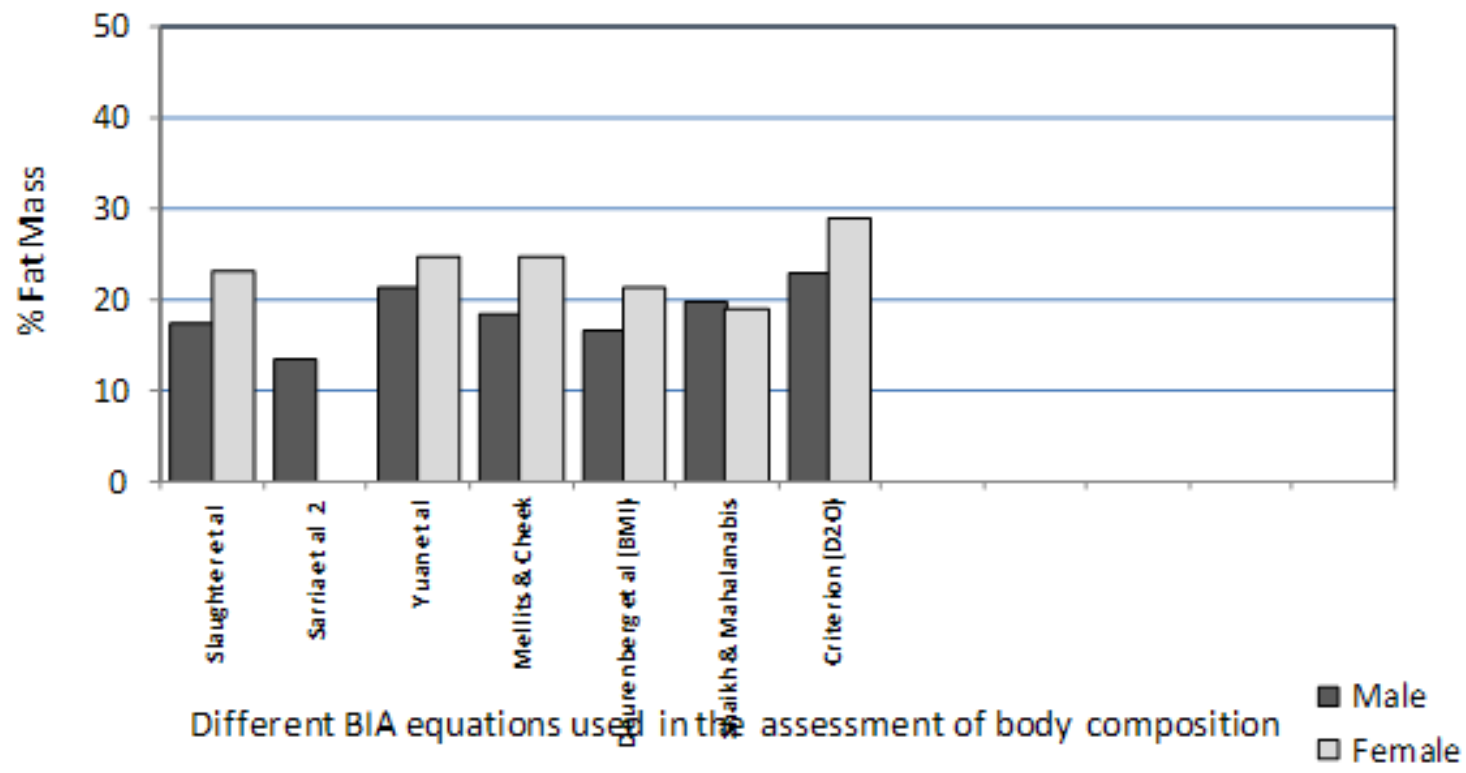

Figure 4: Percentage FM estimated by BIA and criterion method in Sri Lankan children

Although the existing prediction equations did not give satisfactory results in the assessment of body composition of Sri Lankan children, there was a significant association between TBW and impedance index in both boys $\left(\mathrm{R}^{2}=86.2 \% ; \mathrm{p}<0.001\right)$ and girls
$\left(\mathrm{R}^{2}=81.0 \% ; \mathrm{p}<0.001\right)$ denoting that new BIA prediction equation could be developed for Sri Lankan children ${ }^{20}$. Based on this relationship a final prediction equations to assess TBW and FFM was developed for Sri Lankan children (table 3$)^{46}$.

Table 3: Final, gender combined BIA prediction equation for estimation of TBW \& FFM in Sri Lankan children

\begin{tabular}{|l|c|c|c|c|}
\hline \multicolumn{1}{|c|}{ Equation } & \multicolumn{2}{|c|}{ Goodness of fit } & \multicolumn{2}{c|}{ PRESS procedure } \\
\hline & $\boldsymbol{R}^{\mathbf{2}}$ & $\boldsymbol{R M S E}$ & $\begin{array}{c}\text { PRESS statistic } \\
\text { (PRESS residuals) }\end{array}$ & PRESS R $^{\mathbf{2}}$ \\
\hline $\begin{array}{l}\text { TBW = 0.41 impedance index + 0.17 } \\
\text { weight + 1.1 sex code + 0.44 }\end{array}$ & 86.3 & 2.1 & $2.1(1.2)$ & 85.8 \\
\hline $\begin{array}{l}\text { FFM = 0.56 impedance index + 0.22 } \\
\text { weight + 1.6 sex code -0.22 }\end{array}$ & 86.9 & 2.7 & $2.8(1.4)$ & 86.5 \\
\hline
\end{tabular}




\section{Anthropometry based body composition assessment}

\section{Skin-fold thickness}

Anthropologists have appreciated the anthropometric value of subcutaneous fat in the assessment of nutritional status of humans' for many years. In 1953 Tanner first described the use of Harpenden skinfold caliper to measure SFT which is a proxy measure of total body $\mathrm{fat}^{47}$. Since then the instrument has evolved yet preserving its original mechanics and measurement techniques.

Subcutaneous fat deposition is influenced by sex, chronological age, race, state of maturation and socioeconomic status ${ }^{48}$. There is a clear racial difference in subcutaneous fat patterns assessed by SFT. Girls of Asian and Mexican origins have more centrally distributed fat than girls of European and African origins. African children have thinner SFT than white Caucasian children except for the subscapular SFT. This distribution is explained by the influence of environments on evolution. Europeans needed a heat conserving body composition whereas Africans needed to dissipate more energy and could achieve this by having a thin tall body with long limbs. Therefore they have less subcutaneous fat in the periphery and have fat stores for energy on the back of chest.

Age and gender influence subcutaneous fat patterning in body. At birth infants have equal amounts of central and peripheral subcutaneous adipose tissue. Central to peripheral ratio reduces to a lowest point at about 5 years of age. Up to about 13 years it increases in both gender groups. During adolescence males gain more central subcutaneous adipose tissue than peripheral subcutaneous adipose tissue $(\mathrm{C}: \mathrm{P}>1)$, whereas females gain fat in both areas of body $(\mathrm{C}: \mathrm{P}$ $=1)^{49}$.

In Sri Lankan children the peripheral subcutaneous tissue distribution measured by triceps and biceps skinfold thickness showed to have the lowest distribution at six years of age and thereafter it increased with age. Similar pattern of distribution was seen in central adipose tissue measured by subscapular and suprailiac skinfold thickness ${ }^{50}$. Central to peripheral skinfold thickness ratio remained more or less static during 5-14 years of age but it is more than one denoting that there is more central fat deposition than peripheral fat deposition. The ratio of peripheral skinfold thickness to total fat mass and central skinfold thickness to total fat mass showed a reduction despite an increase in total FM with increase in age ${ }^{50}$. This denotes that more fat is deposited as visceral adipose tissue than subcutaneous adipose tissue.

SFT based regression equations are used to estimate body composition but none have been developed on South Asian populations. Several prediction equations used in the published literature were validated on Sri Lankan children and most give inaccurate results in the assessment of body composition (figure 5) (1 $^{2}$. A new skin fold equation was developed for Sri Lankan children (table 4) ${ }^{51}$.

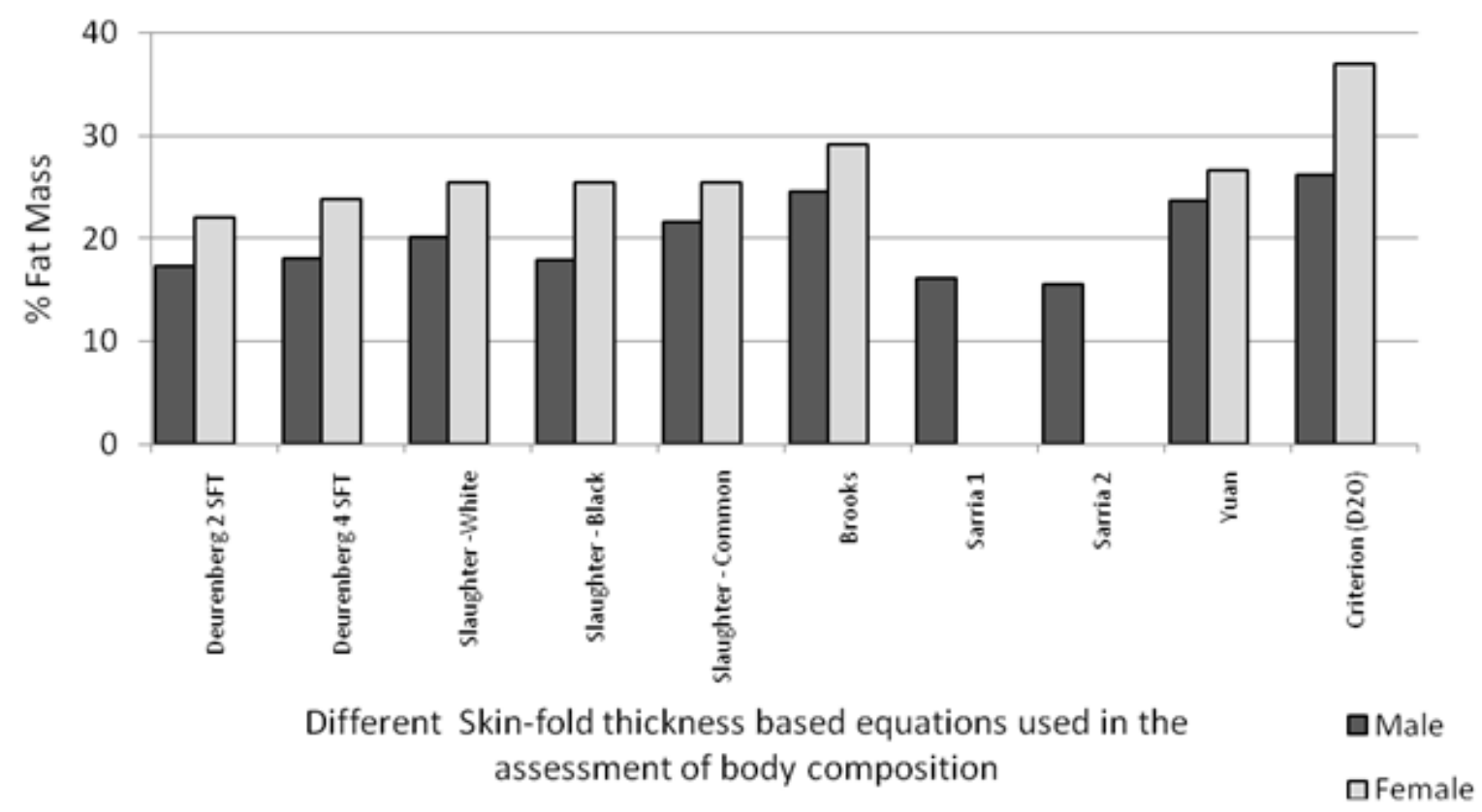

Figure 5: \% FM estimated by skinfold thickness equations and criterion method in Sri Lankan children 
Table 4: Final, gender combined, skinfold thickness prediction equation for FM \& \%FM in Sri Lankan children

\begin{tabular}{|l|c|c|c|c|}
\hline Equation & Goodness of fit & \multicolumn{2}{c|}{ PRESS procedure } \\
\hline & $\boldsymbol{R}^{2}$ & $\boldsymbol{R M S E}$ & $\begin{array}{c}\text { PRESS statistic } \\
(\text { PRESS residuals })\end{array}$ & PRESS R $^{2}$ \\
\hline $\begin{array}{l}\text { FM= (0.68 } \times \text { Age) }+(0.246 \times \text { SFT-Tricep) }+ \\
(0.383 \times \text { SFTSS })-(1.61 \times \text { Sex Code })-3.45\end{array}$ & 76.4 & 3.4 & $3.4(1.5)$ & 75.6 \\
\hline $\begin{array}{l}\text { \% FM= (-0.28 } \times \text { Age })+(0.49 \times \text { SFT-Tricep })+ \\
(0.34 \times \text { SFTSS })-(7.97 \times \text { Sex Code })+26.8\end{array}$ & 46.9 & 8.6 & $8.7(2.6)$ & 44.8 \\
\hline
\end{tabular}

\section{Height and weight based equation}

There are only a few published height and weight based equations used in the assessment of body composition. It is a simple technique accessible to many involved in child care. A new equation was developed for Sri Lankan children (table 5) ${ }^{52}$.

Table 5: Final, gender combined, height \&weight prediction equation for estimation of TBW in Sri Lankan children

\begin{tabular}{|l|c|c|c|c|}
\hline \multicolumn{1}{|c|}{$\begin{array}{c}\text { Final prediction equation for TBW } \\
\text { estimation }\end{array}$} & \multicolumn{2}{|c|}{ Goodness of fit } & \multicolumn{2}{|c|}{ PRESS procedure } \\
\cline { 2 - 5 } & $\boldsymbol{R}^{2}$ & $\boldsymbol{R M S E}$ & $\begin{array}{c}\text { PRESS statistic } \\
\text { (PRESS residuals) }\end{array}$ & $\boldsymbol{P R E S S ~ R}^{2}$ \\
\hline $\begin{array}{l}\text { 0.13 Height }+0.27 \text { Weight }+1.82 \text { Sex Code - } \\
10.35\end{array}$ & 83.4 & 2.3 & $2.32(1.3)$ & 82.9 \\
\hline
\end{tabular}

\section{Conclusions Phase I}

This part of my study has shown that:

- Current BMI based cutoff values are not sensitive in diagnosing obesity in Sri Lankan children.

- Newly developed BMI and WC cutoff show agreement with results from similar studies.

- Body composition techniques developed on groups of other ethnic origins are not suitable for assessment.

- Appropriate body composition methods can be developed for accurate assessment of body composition of Sri Lankan children.
Assessment of body composition of Sri Lankan Australian children

Socioeconomic status as well as living environment influences body composition as shown by Deurenberg et $\mathrm{al}^{32}$. This effect has to be evaluated as it is of concern to the health of migrant children. It would be important to see how much of their original genetic phenotype would get altered in these different environments. A group of 42 Australian children of Sri Lankan origin, living in Brisbane, Australia [60\% born in and 40\% living for 6.8 (range 3.1-10.2yrs)] were studied.

\section{Diagnosis of obesity}

Obesity in Australian children of Sri Lankan origin was evaluated using different diagnostic methods ${ }^{19}$. Based on $\% \mathrm{FM} 59 \%$ of boys and $46 \%$ of girls were diagnosed to be obese (table 6).

Table 6: Cases of obesity and overweight diagnosed by different methods in Australian children by gender and ethnic origin

\begin{tabular}{|l|c|c|}
\hline \multicolumn{1}{|c|}{ Obesity diagnosed by; } & Male $(27)$ & Female (15) \\
\hline$\%$ FM & $16(59 \%)$ & 0 \\
\hline IOTF & 0 & 1 \\
\hline CDC & 2 & 1 \\
\hline BMI-Z $>$ 2SD & 2 & 3 \\
\hline$\%$ FM centile & 7 & 4 \\
\hline WC & 5 & $6(40 \%)$ \\
\hline New Sri Lankan cutoff values & $8(30 \%)$ & $8(53 \%)$ \\
\hline BMI & $11(40 \%)$ & \\
\hline WC &
\end{tabular}


IOTF based BMI cutoffs did not detect a single case of obesity in this group of children. New Sri Lankan cutoff values for BMI and WC were able to detect more obese children and WC was a better tool. All methods showed high specificity, but low sensitivity. BMI showed a high correlation with FM ( $\mathrm{r}=0.92$; $\mathrm{p}<0.001)$ but not with $\% \mathrm{FM} \quad(\mathrm{r}=0.68 ; \mathrm{p}<0.001)$, which made the BMI a poor indicator of obesity. WC showed a statistically significant high correlation with $\mathrm{FM} \quad(\mathrm{r}=0.91 ; \mathrm{p}<0.001)$ and $\% \mathrm{FM} \quad(\mathrm{r}=0.62$; $\mathrm{p}<0.001)$.

Assessment of body composition using different prediction equations

Body composition of these children was studied using above mentioned 11 BIA equations developed on children of other ethnic origins (figure 6).

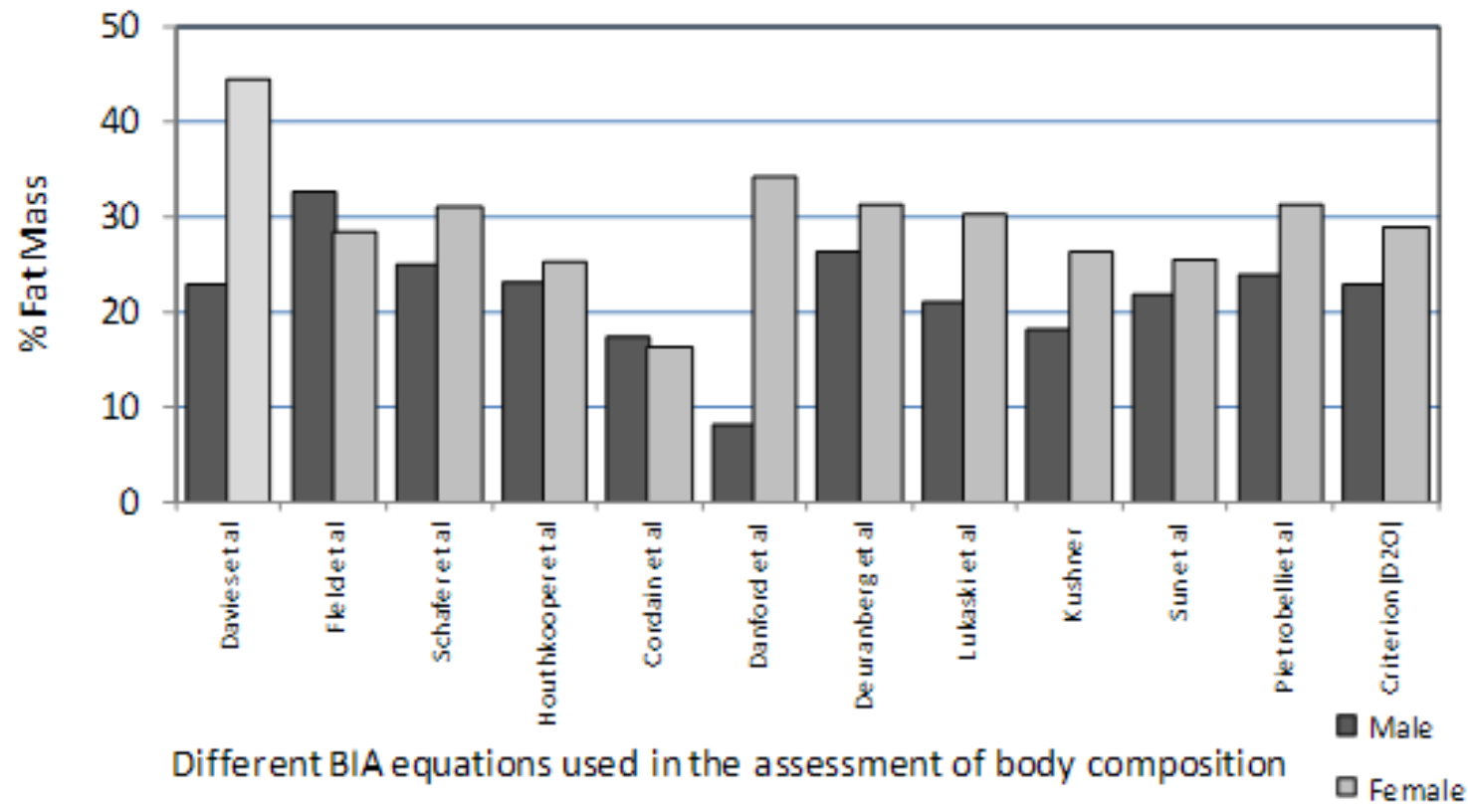

Figure 6: Percentage FM estimated by BIA in Australian children of Sri Lankan origin

These equations did not show satisfactory assessment of body composition ${ }^{53}$. Similarly anthropometry based equations did not give acceptable results in the assessment of body composition of these Australian children (Figure 7$)^{44}$.

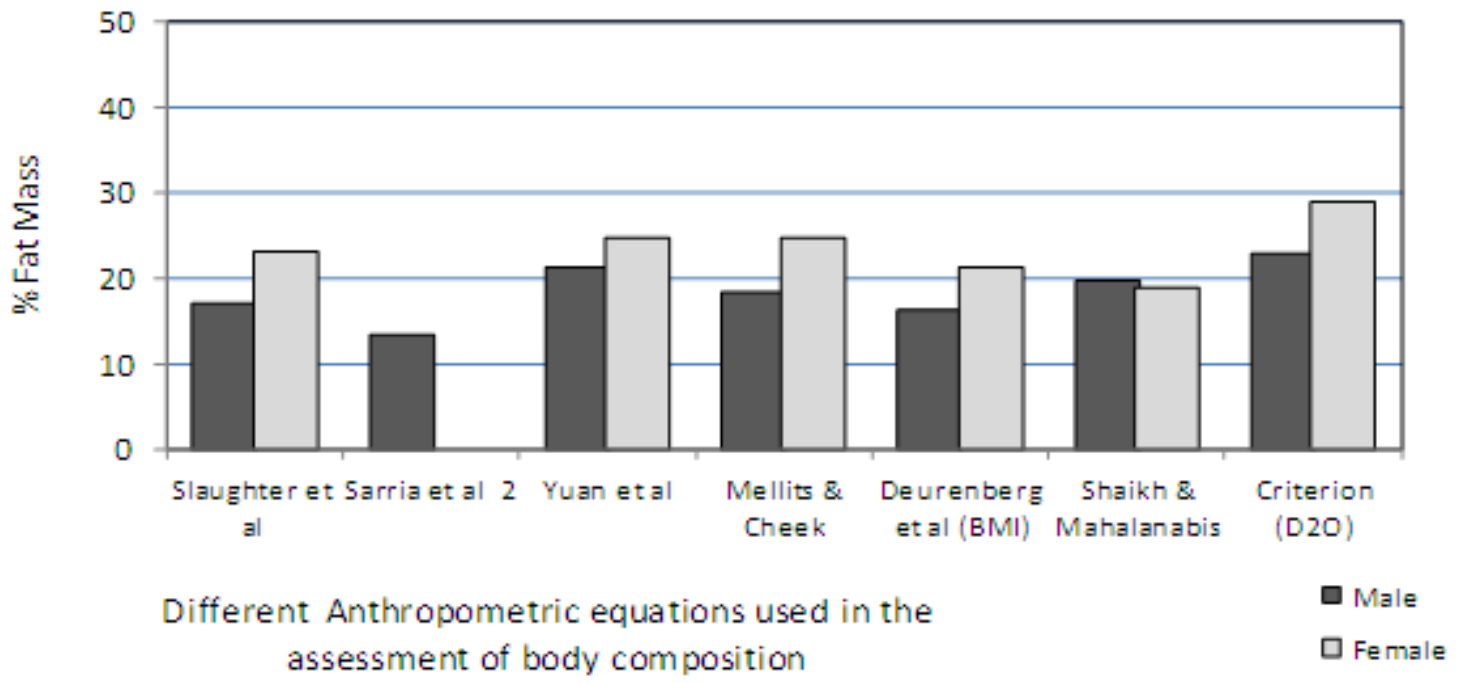

Figure 7: \%FM estimated by Anthropometric methods in Australian children of Sri Lankan origin 
Use of equations developed in Sri Lanka

Body composition of Sri Lankan Australian children were assessed using equations developed and published by us (produced on Sri Lankan children $)^{46,51,52}$. The BIA, SFT and Height-weight based equations gave results which did not differ significantly from the assessments made by criterion method (Figure 8).

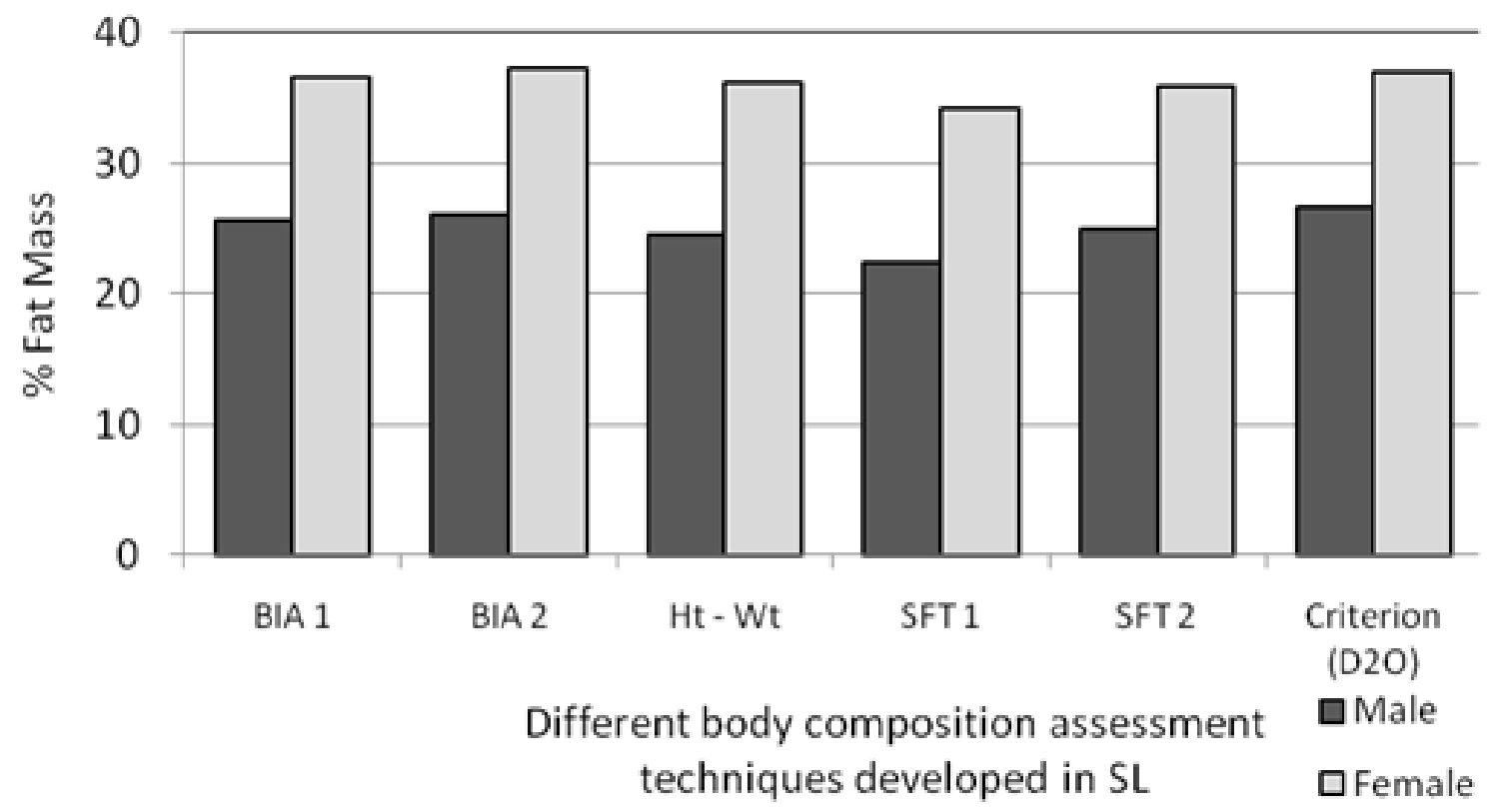

Figure 8: \%FM estimated by Sri Lankan equations in Australian children of Sri Lankan origin

\section{Conclusions of Phase II}

Data of this component of the study showed that:

- Current BMI based cutoff values are not sensitive in Sri Lankan children living in Australia.

- The proposed New Sri Lankan BMI cutoff are the best for overweight screening in Sri Lankan children living in Australia.

- Body composition assessment techniques work best on populations having same ethnic origin

Impact of ethnicity and socioeconomic environment on body composition

BMI Z score was plotted against the $\% \mathrm{FM}$ of native Sri Lankan, Australian Sri Lankan and an age matched Australian Caucasian children. The 3 lines of best fit for each group lie parallel to each other with native Sri Lankan line at top and Australian Caucasians line at bottom, denoting that at any given BMI Z score, native Sri Lankan children had the highest \%FM while the Australian Caucasian children had the lowest \%FM (figure 9).

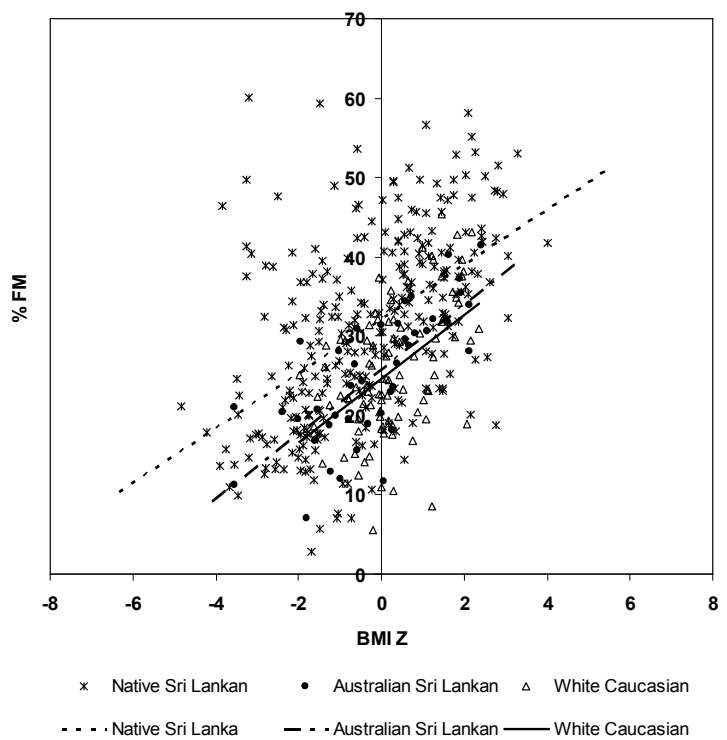

Figure 9: Association between BMI-Z and \%FM assessed by criterion method for Sri Lankan children, Australian Sri Lankan and Australian White Caucasian children 
Difference between Sri Lankan and two groups of Australian children were statistically significant. This clearly shows that Sri Lankan children have higher percentage of body fat. The difference in \%FM between Australian children of Sri Lankan Caucasian origin was not significant. This shows that the living environment has influenced the body composition to some extent. Similar results were shown by Deurenberg et $a l^{32}$ in their meta-analysis where European white Caucasians has a higher percentage of fat compared to their counterparts living in North America.

\section{Conclusions}

Our data shows that body composition is a complex issue and many factors influence it. Data presented here clearly showed that ethnicity as well as living environment influences the body composition. People living in same environments will have somewhat similar body composition at least if FM is considered. Body composition assessment equations developed on children of an ethnic group are best applied on children of same ethnic origin even when living in different condition and countries than equations developed on children of different ethnic origins. Universal application of obesity cutoff values underestimate overweight and obesity in Sri Lankan populations. Therefore cutoff values and assessment techniques cannot be generalized but need to be ethnic specific than population specific.

Caution has to be exerted when using international growth references in assessing growth of South Asian children. As much as international cutoff values underestimate overweight and obesity, they could overestimate undernutrition. Therefore programmes directed to eliminate undernutrition could lead our children to become overweight and go undetected for many years resulting in many chronic illnesses later in life. Therefore it is of paramount importance that paediatricians bear in mind that Sri Lankan children have a different body composition and take serious note when assessing and categorizing the nutritional status of our children.

\section{Future}

Therefore as I see the future, to combat the ever rising non communicable disease prevalence in our region BMI cutoff needs to be redefined for South Asian populations for which I have now contributed alongside other authors. Body composition associated with metabolic risk needs evaluation and body composition assessment techniques should be adopted in routine clinical practice. Aim should be to correct body composition rather than anthropometry in prevention and treatment of NCD.

\section{References}

1. Wang ZM, Pierson Jr RN, Heymsfield SB. The five-level model: a new approach to organizing body composition research. American Journal of Clinical Nutrition 1992; 56:19-28.

2. Van Loan MD. Body composition in disease: What can we measure and how can we measure it? Acta Diabetalogia 2003; 40:S154-S157.

3. Yajnik CS and Yudkin JS. The Y-Y paradox. The Lancet 2004; 363:163. http://dx.doi.org/10.1016/S0140-6736(03)15269-5

4. Bell NA, McClure PD, Hill RJ, Davies PSW. Assessment of foot-to-foot bioelectrical impedance for the prediction of total body water. European Journal of Clinical Nutrition 1998; 52:856-9. http://dx.doi.org/10.1038/sj.ejen.1600661

5. Schoeller DA. Hydrometry. In: Human body composition. Editors: Roche AF, Heymsfield SB, Lohman TG. Human Kinetics, Champaign IL: 1996. 25-43.

6. Halliday D, Miller AG. Precise measurement of total body water using trace quantities of deuterium oxide. Biomedical Mass Spectrometry 1977; 4(2):82-7. http://dx.doi.org/10.1002/bms.1200040205

7. Lohman TG. Assessment of body composition in children. Pediatric Exercise Science 1989; 1:1930 .

8. Callaway CW, Chumlea WC, Bouchard C et al. Circumferences. In: Anthropometric Standardization Reference Manual. Editors: Lohman TG, Roche AF, Martorella R. Human Kinetics, Champaign IL: 1988. 55-80.

9. Owen GM. Measurement, recording and assessment of skinfold thickness in children and adolescence: report of a small meeting. American Journal of Clinical Nutrition 1982; 35:629-638. 
10. Harrison GG, Bushkirk ER, Carter JEL et al. Skinfold thickness and measurement technique. In: Anthropometric Standardization Reference Manual. Editorss: Lohman TG, Roche AF, Martorella R. Human Kinetics, Champaign IL: 1988. 55-80.

11. Baumgartner RN. Electrical impedance and total body electrical conductivity. In: Human Body Composition. Editors: Roche AF, Heymsfield SB, Lohman TG. Human Kinetics, Champaign IL: 1996.79-107.

12. Lohman TG. The prevalence of obesity in children in the United States. In: Advances in body composition assessment. Human Kinetics, Champaign, IL: Monogram 1992.79-89.

13. Cole TJ, Bellizzi MC, Flegal KM, Dietz WH. Establishing a standard definition for childhood overweight and obesity worldwide: international survey. British Medical Journal 2000; 320:1-6. http://dx.doi.org/10.1136/bmj.320.7226.1

14. Kuczmarski RJ, Ogden CL, Grummer-Strawn LM et al. CDC Growth Charts: United States. Advance Data 2000; 314: 24-5.

15. Cole TJ, Freeman JV, Preece MA. Body mass index reference curves for the UK, 1990. Archives of Disease in Childhood 1995; 73, 259. http://dx.doi.org/10.1136/adc.73.1.25

16. McCarthy HD, Cole TJ, Fry T, Jebb SA, Prentice AM. Body fat reference curves for children. International Journal of Obesity Related Metabolic Disease 2006; 30, 598-602.

17. McCarthy HD, Jarrett KV, Crawley HF. The development of waist circumference percentiles in British children aged 5.0-16.9yrs. European Journal of Clinical Nutrition 2001; 55(10):9027. http://dx.doi.org/10.1038/sj.ejcn.1601240

18. Himes JH, Bouchard C. Validity of anthropometry in classifying youth as obese. International Journal of Obesity Related Metabolic Disease 1989; 13:183-93.
19. Wickramasinghe VP, Cleghorn GJ, Edmiston KA, Murphy AJ, Abbott RA, Davies PSW. Validity of BMI as a measure of obesity in Australian white Caucasian and Australian Sri Lankan children. Annals of Human Biology 2005; 32 (1): 60-72. http://dx.doi.org/10.1080/03014460400027805

20. Wickramasinghe VP, Lamabadusuriya SP, Cleghorn GJ, Davies PSW. Use of bioelectrical impedance in Sri Lankan children: Comparison of several prediction equations. International Journal of Body Composition Research 2008; 6(1): $1-8$.

21. Wickramasinghe VP, Lamabadusuriya SP, Cleghorn GJ, Davies PSW. Use of skinfold thickness in Sri Lankan children: Comparison of several prediction equations. Indian Journal of Paediatrics 2008; 75(12):1237-42.

22. Bland JM, Altman DG. Statistical methods for assessing agreement between two methods of clinical measurement. Lancet 1986; 1(8476):307-10.

23. Dawson B. Trapp RG. Basic \& clinical biostatistics. $3^{\text {rd }}$ Ed. International Edition. Lange Medical Books/McGraw-Hill, Singapore. 2001.

24. Guo SS, Chumlea WC. Statistical methods for the development and testing of predictive equations. In: Human Body Composition. Editors: Roche AF, Heymsfield SB, Lohman TG. Human Kinetics, Champaign IL: 1996.191202.

25. Sun SS, Chumlea WC, Heymsfield SB, et al. Development of bioelectrical impedance analysis prediction equations for body composition with the use of a multi-component model for use in epidemiological surveys. American Journal of Clinical Nutrition 2003; 77(2):331-40.

26. Wickramasinghe VP, Lamabadusuriya SP, Cleghorn GJ, Davies PSW. BMI as a measure of obesity in Sri Lankan children: validity of currently used cut off values. The Ceylon Medical Journal 2009; 54(4):114-9. 
27. Flegal KM, Ogden CL, Wei R, Kuczmarski R, Johnson CL. Prevalence of overweight in US children: comparison of US growth charts from the centers for disease control and prevention with other reference values for body mass index. American Journal of Clinical Nutrition 2001; 73:1086-93.

28. Duncan JS, Schofield G, Duncan EK, Rush EC. Classifying childhood obesity in a multiethnic population: comparisons among five major ethnic groups. O27 Abstract. International Journal of Body Composition Research 2005; 3(3):89.

29. Hattori K, Tatsumi N, Tanaka S. Assessment of body composition by using a new chart method. American Journal of Human Biology 1997; 9:573-8. http://dx.doi.org/10.1002/(SICI)15206300(1997)9:5<573::AID-AJHB5 $>3.0 . C O ; 2-\mathrm{V}$

30. Lazarus R, Baur L, Webb K, Blyth F. Body mass index is screening for adiposity in children and adolescents: systematic evaluation using receiver operator characteristic curves. American Journal Clinical Nutrition 1996; 63: 500-6.

31. Pietrobelli A, Faith MS, Allison DB, Gallagher D, Chiumello G, Heymsfield SB. Body mass index as a measure of adiposity among children and adolescents: A validation study. Journal of Pediatrics 1998; 132(2): 204-10. http://dx.doi.org/10.1016/S0022-3476(98)70433-0

32. Deurenberg P, Yap M, Van Staveren WA. Body mass index and percent body fat: a meta-analysis among different ethnic groups. International Journal of Obesity Related Metabolic Disease 1998; 22:1164-71.

33. Misra, A. Revisions of cutoffs of body mass index to define overweight and obesity are needed for the Asian-ethnic groups. International Journal of Obesity Related Metabolic Disease 2003; 27:1294-6.

34. Stevens J. Ethnic-specific revisions of body mass index cut-offs to define over weight and obesity in Asians are not warranted. International Journal of Obesity Related Metabolic Disease 2003; 27: 1297-9.
35. WHO. Appropriate body-mass index for Asian populations and its implications for policy and intervention strategies. Lancet 2004: 363: 157-63. http://dx.doi.org/10.1016/S0140-6736(03)15268-3

36. Wickramasinghe VP, Lamabadusuriya SP, Cleghorn GJ, Davies PSW. Defining anthropometric cut-off levels related to metabolic risk in a group of Sri Lankan children. Annals of Human Biology. Advance online publication. http://dx.doi.org/10.3109/03014460.2011.57350 $\underline{5}$.

37. Katulanda P, Jayawardena MAR, Sheriff MHR, Matthews DR. 2010. Derivation of anthropometric cut-off levels to define CVD risk in Sri Lankan adults. Bri J Nutr Advance online publication. 1-7. http://dx.doi.org/1017/S0007114510004563.

38. Razak F, Anand SS, Shannon H, et al. Defining obesity cut off point in a multiethnic population. Circulation 2007; 115:2111-8. http://dx.doi.org/10.1161/CIRCULATIONAHA. $\underline{106.635011}$

39. Goran MI, Gower BA, Treuth M, Nagy TR. Prediction of intra-abdominal and subcutaneous abdominal adipose tissue in healthy prepubertal children. International Journal of Obesity Related Metabolic Disease 1998; 22:549-58.

40. Taylor RW, Jones IE, William SM, Grulding A. Evaluation of waist circumference, waist to hip ratio and conicity index as screening tools for high trunk fat mass as measured by dual energy x-ray absorptiometry. American Journal of Clinical Nutrition 2000; 72: 490-5.

41. De Silva KSH, Wickramasinghe VP, Goonerathne INA. Metabolic consequences of childhood obesity: a preliminary report. The Ceylon Medical Journal 2006; 51(3):105-9.

42. Power C, Lake JK, Cole TJ. Measurement and long term health risks of child and adolescent fatness. International Journal of Obesity Related Metabolic Disease 1997; 21:507-26.

43. Deurenberg-Yap M, Deurenberg P. Is a reevaluation of WHO body mass index cut-off values needed? The case of Asians in Singapore. Nutrition Reviews. 2003; 61(5):S80-S87.

http://dx.doi.org/10.1301/nr.2003.may.S80-S87 
44. Wickramasinghe VP, Cleghorn GJ, Edmiston KA, Davies PSW. Impact of ethnicity upon body composition assessment in Sri Lankan Australian Children. Journal of Paediatrics and Child Health 2005: 41:101-6.

http://dx.doi.org/10.1111/j.14401754.2005.00558.x

45. Ellis KJ. Human body composition: In vivo methods. Physiological Reviews. 2000; 80 (2):649-80.

46. Wickramasinghe VP, Lamabadusuriya SP, Cleghorn GJ, Davies PSW. Assessment of body composition in Sri Lankan children: Validation of a bioelectrical impedance prediction equation. European Journal of Clinical Nutrition 2008; 62(10):1170-7.

http://dx.doi.org/10.1038/sj.ejcn.1602835

47. Durnin JVGA, De Bruin H, Feunekes GIJ. Skinfold thickness: Is there a need to be very precise in their location? British Journal of Nutrition 1997; 77:3-7. http://dx.doi.org/10.1017/S000711450000283X

48. Shalitin S, Phillip M. Role of obesity and leptin in the pubertal process and pubertal growth - a review. International Journal of Obesity Related Metabolic Disease 2003; 27; 869-74.

49. Pietrobelli A, Andreoli A, Cerelli V, Carbonelli MG, Peroni DG, Lorenzo A De. Predicting fatfree mass in children using bioimpedance analysis. Acta Diabetologia 2003; 40:S212S215.
50. Wickramasinghe VP. Skin-fold thickness in Sri Lankan children" in Editors Victor R Preedy "Handbook of Antrhropometry: Physical Measures of Human Form in Health and Disease" Chapter 77. Springer USA. (In Press).

51. Wickramasinghe VP, Lamabadusuriya SP, Cleghorn GJ, Davies PSW. Assessment of body composition in Sri Lankan children: Validation of a skinfold thickness equation. The Ceylon Medical Journal 2008; 53(3): 83-8.

52. Wickramasinghe VP, Lamabadusuriya SP, Cleghorn GJ, Davies PSW. Development of height-weight based equation for assessment of body composition in Sri Lankan Children. Indian Journal of Pediatrics 2010; 77(2):155-60. http://dx.doi.org/10.1007/s12098-009-0333-5

53. Wickramasinghe VP, Cleghorn GJ, Edmiston KA, Murphy AJ, Abbott RA, Davies PSW. Ability of bioelectrical impedance to predict percentage fat mass in children of two different ethnic origins. International Journal of Body Composition Research 2005; 3(1): 5-14. 